Research Article

\title{
Preparation and Antibacterial Activity of New Azo- Schiff Thiazol Ligand and Some of its Metal Complexes
}

\author{
Eateman Salah Mahdi ${ }^{\simeq}$, Raheem Tahir Mahdi Al-Sa'edi \\ Department of Chemistry, College of Education for Girls, University of Kufa, An Najaf, Iraq. \\ Corresponding author. E-mail: eatemanalmaamorii93@gmail.com
}

Received: Jul. 7, 2018; Accepted: Jul. 23, 2018; Published: Nov. 19, 2018.

Citation: Eateman Salah Mahdi, Raheem Tahir Mahdi Al-Sa'edi, Preparation and Antibacterial Activity of New Azo-Schiff Thiazol Ligand and Some of its Metal Complexes. Nano Biomed. Eng., 2018, 10(4): 369-378.

DOI: 10.5101/nbe.v10i4.p369-378.

\begin{abstract}
New chelate compounds, with general formula $\left.\left[\mathrm{M}\left(\mathrm{HL}_{1}\right)_{2}\right]\left(\mathrm{H}_{2} \mathrm{O}\right)_{2}, \mathrm{M}=\mathrm{Co}(\mathrm{II}), \mathrm{Ni}(\mathrm{II}), \mathrm{Cu}(\mathrm{II})\right]$ and $\left[\mathrm{M}\left(\mathrm{HL}_{1}\right)_{2}\right]\left(\mathrm{H}_{2} \mathrm{O}\right), \mathrm{M}=\mathrm{Zn}(\mathrm{II}), \mathrm{Cd}(\mathrm{II}), \mathrm{Hg}(\mathrm{II})$, were prepared by reacting chlorid salt of these metals with the new azo Schiff-base ligand 4-((E)-(3-bromo phenyl)diazenyl)-2-((E)-(thiazol-2ylimino) methylphenol $\mathrm{HL}_{1}$ using the coupling of diazonium salt of 3-bromoaniline with (E)-2(thiazol-2-ylimino) methyl phenol. The new azo Schiff thiazol ligand and its chelate complexes were characterized by available spectra and analytical methods such as mass spectra, proton nuclear magnetic resonance $\left({ }^{1} \mathrm{H}-\mathrm{NMR}\right)$, infrared (IR) spectroscopy, ultraviolet-visible spectroscopy (UVVis), elemental analysis (CHN), molar conductivity and magnetic susceptibility measurements. Results showed that the ratio of metal:ligand was $1: 2$, and also showed that $\mathrm{Co}(\mathrm{II}), \mathrm{Ni}(\mathrm{II})$, and $\mathrm{Cu}(\mathrm{II})$ chelate complexes had octahedral geometry, while $\mathrm{Zn}(\mathrm{II}), \mathrm{Cd}(\mathrm{II})$ and $\mathrm{Hg}(\mathrm{II})$, had tetrahedral geometry. The ligand with its complexes was tested in vintor against the sensitive organisms, including Staphylococcus aureus (gram positive) and Pseudomonas aeruginosa (gram negative). The study showed that the prepared metal complexes had more biological affectivity than the ligands themselves.
\end{abstract}

Keywords: Azo-Schiff thiazol; Chelate complexes; Biological study

\section{Introduction}

A great deal of work has been reported on the synthesis and characterization of many different types of azo Schiff-base ligands in coordination chemistry. Due to the excellent donor properties of the azo and azo methine group [1, 2], these ligands have been reported to show a wide range of varity in biological actions because of azomethine linkage which is responsible for antibacterial, antifungal, herbicidal, clinical and analytical activities [1, 4].
The presence of different atoms as the donor of electrons in the structure of azo Schiff-base ligands, such as $\mathrm{O}, \mathrm{N}$ and $\mathrm{S}$ atoms, gives the ability of coordination between these ligands as lowes base and transition metal as lowes acid, in order to form coordination complexes with different geometrical shapes, depending on the coordination number. On the other hand, the importance of azo compounds such as thiazolyl azo dyes were found in applications such as leather, polymer, paper, paint, textiles and coating industries as a dyeing agent [5]. 1n the present study, 
novel thiazol Schiff-base ligand $\left(\mathrm{HL}_{1}\right)$ with its metal complexes was synthesized and characterized by various spectral analysis, their biological activities having also been studied.

\section{Experimental}

\section{Materials and instruments}

Cobalt(II) chloride hexa hydrate $\mathrm{CoCl}_{2} \cdot 6 \mathrm{H}_{2} \mathrm{O}(99 \%)$, glacial acetic acid $\mathrm{CH}_{3} \mathrm{COOH}$ (99.5\%), hydrochloric acid $\mathrm{HCl}$ (99\%), m-Toluidine $\mathrm{C}_{7} \mathrm{H}_{9} \mathrm{~N}$ (99\%), silver nitrate $\mathrm{AgNO}_{3}$ (99.5\%) and Zinc(II) chloride $\mathrm{ZnCl}_{2}$ (99\%) were obtained from B.D.H. 2-aminothiazole $\mathrm{C}_{3} \mathrm{H}_{4} \mathrm{~N}_{3} \mathrm{~S}$ (98\%), ammonium hydroxide $\mathrm{NH}_{4} \mathrm{OH}(98 \%)$, cadmium(II) chloride anhydrous $\mathrm{CdCl}_{2}$ (99\%) and 2-hydroxybenzaldehyde $\mathrm{C}_{7} \mathrm{H}_{6} \mathrm{O}_{2}$ (96\%) were obtained from Fluka. Copper(II) chloride dehydrate $\mathrm{CuCl}_{2} \cdot 2 \mathrm{H}_{2} \mathrm{O}$ (99\%) was obtained from Riedel-deHaën. Ethanol absolute $\mathrm{C}_{5} \mathrm{H}_{5} \mathrm{OH}$ (99.5\%) was obtained from GCC. Nickel(II) chloride hexa hydrate $\mathrm{NiCl}_{2} \cdot 6 \mathrm{H}_{2} \mathrm{O} 98 \%$ was obtained from Himedia. Mercuric(II) chloride $\mathrm{HgCl}_{2}$ (99\%) and sodium nitrite $\mathrm{NaNO}_{2}$ (99\%) were obtained from Merck. Staphylococcus aureus and Pseudomonas aeruginosawere were obtained from the Department of Biology, College of Science for Women, Babylon University, which were originally cultured in Teaching Merjan Hospital in Babylon, Iraq.

Stuart melting points SMP10 was used to measure the melting point for solid prepared materials, at College of Science for Women, Kufa University. Shimadzu FTIR 8400S spectrophotometer was used to take infrared (IR) spectra, at College of Pharmacy, Kufa University. Shimadzu UV-1700 spectrophotometer was used to measure the ultraviolet (UV)-visible absorption spectra of ligand and complex solutions in ethanol as solvents for solid materials, at College of Science for Women, Kufa University. Shimadzu AA-6300 Atomic Absorption/Flame Emission Spectrophotometer was used to measure the concentration of some metal ions, in the biochemical laboratory, Kufa University. C.H.N. mth EA 99 was used to determine the percentages of carbon $\odot$, hydrogen $(\mathrm{H})$ and nitrogen $(\mathrm{N})$ elements in the prepared ligand and their solid complex compounds at Ahlulbait University, Jordon. Digital Conductivity SeriesIno Lab 720 was used to measure the molar conductivity of prepared chelate complexes in dimethyl sulfoxide in the biochemical laboratory, Kufa University. Balance Magnetic Susceptibility Model-M. S.B Auto was used to measure the magnetic sensitivity of prepared chelate complexes at room temperature, at the Department of Chemistry, College of Education, Al-Mustansiriya University. Proton nuclear magnetic resonance $\left({ }^{1} \mathrm{HNMR}\right)$ spectra were recorded with Brucker (300 MHz) using tetrametheylsilane (TMS) as an internal standard, and dimethyl sulfoxide (DMSO) as a solvent at Shahid Beheshti University of Medical Sciences and Health Services, Tehran, Iran.

\section{Preparation of (E)-2-((thiazol-2-ylimino)methyl) phenol (SB)}

Schiff base prepared by the condensation reaction of thiazol-2-amine with 2-hydroxybenzaldehyde by dissolving $1 \mathrm{~g}$ of $0.01 \mathrm{~mol}$ thiazol-2-amine in $20 \mathrm{~mL}$ of absolute ethanol, and then being mixed with a solution of $1.06 \mathrm{~mL}$ of $0.01 \mathrm{~mol} 2$ - hydroxyl benzaldehyde dissolved in $20 \mathrm{~mL}$ of the same solvent with the addition of one drop of glacial acetic acid, followed by reflux for $6 \mathrm{~h}$ [6]. The solution was left to cool then poured over the ice; the appearance of yellow precipitate was observed. It was filtered, dried and recrystallized from hot absolute ethanol to get yellow pure crystals of Schiff base. The yield was found equal to $73 \%$ and melting point reached to $72{ }^{\circ} \mathrm{C}$. Scheme 1 describes preparation of the Schiff base (SB).

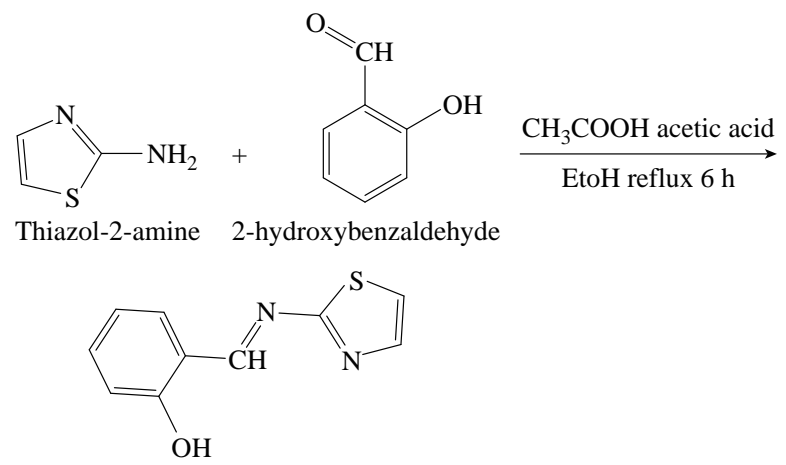

(E)-2-((thiazol-2-ylimino)methyl)phenol

Scheme 1 Syntheses of the Schiff base.

\section{Preparation of azo Schiff-base ligand 4-((E)- (3-bromophenyl)diazenyl)-2-((E)-(thiazol-2- ylimino)-methyl)phenol (HL1)}

Azo Schiff-base ligand was prepared according to the following general procedure [7]. $1.08 \mathrm{~mL}$ of 0.01 mol 3- Bromoaniline was dissolved in a mixture of 3 $\mathrm{mL}$ hydrochloric acid and $20 \mathrm{~mL}$ of distilled cold water, and diazotized below $0{ }^{\circ} \mathrm{C}$ with $0.7 \mathrm{~g}$ of $0.01 \mathrm{~mol}$ sodium nitrite dissolved in $10 \mathrm{~mL}$ of distilled water. Then, the solution was filtered off, and the result was diazonium chloride. The solution was mixed with 2.04 $\mathrm{g}$ of $0.01 \mathrm{~mol}$ SB dissolved in the mixture consisting of 
$150 \mathrm{~mL}$ ethanol and $100 \mathrm{~mL}$ of $10 \%$ sodium hydroxide after being left in the refrigerator for $24 \mathrm{~h}$. The mixture was acidified with dilute hydrochloric acid until $\mathrm{pH}=6$. The precipitate was filtered off and recrystallized twice from hot ethanol and dried. The yield was $80 \%$; the melting point was $89-91{ }^{\circ} \mathrm{C}$. Table 1 shows physical and analytical data of the ligand and its starting materials, Scheme 2 describes preparation of the azo Schiff-base ligand.

\section{Preparation of metal complexes}

The metal complexes ( $1 \mathrm{~mol})$ were prepared by dissolving $0.774 \mathrm{~g} 1 \mathrm{~mol}$ of the ligand in $50 \mathrm{~mL}$ ethanol, added drop by drop whilst stirring, so as to produce a stoichiometric molar ratio of metal : ligand $=$ 1 : 2. The following salts $\mathrm{Ni}(\mathrm{II}), \mathrm{Cu}(\mathrm{II}), \mathrm{Hg}(\mathrm{II}), \mathrm{Cd}(\mathrm{II})$ and $\mathrm{Zn}(\mathrm{II})$ in $25 \mathrm{~mL}$ of absolute ethanol to the solvent and the mixture was heated for $0.5 \mathrm{~h}$, and then left to cool down. A precipitate was observed, filtered off, dried and reconstituted from absolute ethanol to obtain the complex in its pure form.

\section{Antibacterial activity}

The invertor biological screening effects of the investing compound were tested against the bacteria Staphyllo coccous aureus and Pseudomonas aeruginosa by the well-diffusion method using Muller-Hinton agar as medium [8]. Wells of $6 \mathrm{~mm}$ in diameter were made in agar plates by using sterile cork borer; then the agar surface was inoculated with each bacterium. The tested compounds were dissolved in dimethylformamide (DMF) to obtain a solution with the concentration of $100 \mathrm{ppm}$. The plates were incubated at $37^{\circ} \mathrm{C}$ overnight; the zones of inhibition

Table 1 Physical and analytical data of the ligand and its complexes

\begin{tabular}{|c|c|c|c|c|c|c|c|c|c|}
\hline \multirow{2}{*}{ No. } & \multirow{2}{*}{ Chemical formula } & \multirow{2}{*}{ M. wt } & \multirow{2}{*}{$\operatorname{MP}\left({ }^{\circ} \mathrm{C}\right)$} & \multirow{2}{*}{ Color } & \multirow{2}{*}{ Yield (\%) } & \multicolumn{4}{|c|}{ \% Found (Calc.) } \\
\hline & & & & & & $\mathrm{C}$ & $\mathrm{H}$ & $\mathrm{N}$ & M \\
\hline 1 & {$\left[\mathrm{C}_{16} \mathrm{H}_{11} \mathrm{~N}_{4} \mathrm{OSBr}\right]=\mathrm{HL}_{1}$} & 387 & $89-91$ & Brown & 80 & $\begin{array}{c}49.38 \\
(49.61)\end{array}$ & $\begin{array}{c}2.77 \\
(2.84)\end{array}$ & $\begin{array}{c}14.62 \\
(14.47)\end{array}$ & -- \\
\hline 2 & {$\left[\left(\mathrm{CoC}_{16} \mathrm{H}_{10} \mathrm{~N}_{4} \mathrm{OSBr}\right)_{2}\right]\left(\mathrm{H}_{2} \mathrm{O}\right)_{2}$} & 886.47 & 124 & Umber & 86 & $\begin{array}{c}44.08 \\
(44.29)\end{array}$ & $\begin{array}{c}2.59 \\
(2.77)\end{array}$ & $\begin{array}{c}12.17 \\
(12.92)\end{array}$ & $\begin{array}{c}6.65 \\
(6.80)\end{array}$ \\
\hline 3 & {$\left[\mathrm{Ni}\left(\mathrm{C}_{16} \mathrm{H}_{10} \mathrm{~N}_{4} \mathrm{OSBr}\right)_{2}\right]\left(\mathrm{H}_{2} \mathrm{O}\right)_{2}$} & 866.69 & 104 & Dark orange & 76 & $\begin{array}{c}44.11 \\
(44.31)\end{array}$ & $\begin{array}{c}2.68 \\
(2.77)\end{array}$ & $\begin{array}{c}12.75 \\
(12.92)\end{array}$ & $\begin{array}{c}6.89 \\
(6.78)\end{array}$ \\
\hline 4 & {$\left[\mathrm{Cu}\left(\mathrm{C}_{16} \mathrm{H}_{10} \mathrm{~N}_{4} \mathrm{OSBr}\right)_{2}\right]\left(\mathrm{H}_{2} \mathrm{O}\right)_{2}$} & 871.55 & 116 & Yellow & 90 & $\begin{array}{c}44.28 \\
(44.06)\end{array}$ & $\begin{array}{c}2.69 \\
(2.75)\end{array}$ & $\begin{array}{c}12.68 \\
(12.85)\end{array}$ & $\begin{array}{c}7.45 \\
(7.45)\end{array}$ \\
\hline 5 & {$\left[\mathrm{Zn}\left(\mathrm{C}_{16} \mathrm{H}_{10} \mathrm{~N}_{4} \mathrm{OSBr}\right)_{2}\right]\left(\mathrm{H}_{2} \mathrm{O}\right)$} & 885.39 & $155-160$ & Reddish brown & 92 & $\begin{array}{c}44.62 \\
(44.89)\end{array}$ & $\begin{array}{c}2.49 \\
(2.57)\end{array}$ & $\begin{array}{c}12.89 \\
(13.09)\end{array}$ & $\begin{array}{c}7.78 \\
(7.65)\end{array}$ \\
\hline 6 & {$\left[\mathrm{Cd}\left(\mathrm{C}_{16} \mathrm{H}_{10} \mathrm{~N}_{4} \mathrm{OSBr}\right)_{2}\right]\left(\mathrm{H}_{2} \mathrm{O}\right)$} & 902.4 & $145-148$ & Red & 70 & $\begin{array}{c}42.31 \\
(42.55)\end{array}$ & $\begin{array}{c}2.31 \\
(2.44)\end{array}$ & $\begin{array}{c}12.26 \\
(12.41)\end{array}$ & $\begin{array}{c}12.71 \\
(12.46)\end{array}$ \\
\hline 7 & {$\left[\mathrm{Hg}\left(\mathrm{C}_{16} \mathrm{H}_{10} \mathrm{~N}_{4} \mathrm{OSBr}\right)_{2}\right]\left(\mathrm{H}_{2} \mathrm{O}\right)$} & 990.5 & 112 & Brown & 78 & $\begin{array}{c}38.79 \\
(38.67)\end{array}$ & $\begin{array}{c}2.09 \\
(2.22)\end{array}$ & $\begin{array}{c}11.39 \\
(11.28)\end{array}$ & $\begin{array}{c}-- \\
(20.21)\end{array}$ \\
\hline
\end{tabular}

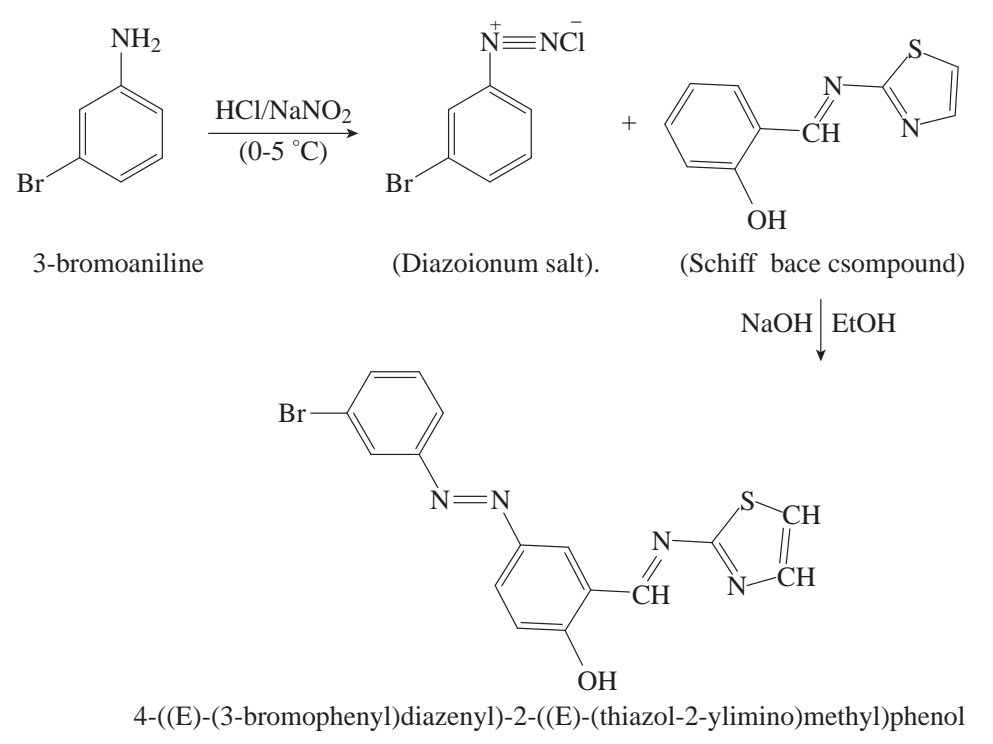

Scheme 2 Syntheses of HL1 ligand. 
formed were measured in millimetres. Each experiment was performed in triplicate and average of the three ages of the three determinations was recorded.

\section{Results and Discussion}

Results of the elemental analyses of the azo Schiff thiazol ligand and its metal chelates were in good agreement with the theoretical expectations. The elemental analyses of coordination compounds show that the ratio of metal : ligand $=1: 2$ existed in all the metal complexes. The molecular conductivity results confirmed for metal chelates in ethanol at $25{ }^{\circ} \mathrm{C}$ were in the range of $11.75-21.31 \mathrm{~S} \mathrm{~m}^{2} \mathrm{~mol}^{-1}$, indicating nonelectrolyte properties in solution, Table 3 shows the measurements of the molar conductivity of complexes.

All the complexes and ligand $\mathrm{HL}_{1}$ were insoluble in water, but highly soluble in DMF and DMSO. The reaction of the heterocyclic azo Schiff thiazol ligand $\mathrm{HL}_{1}$ with metal ions, which was mentioned earlier presented crystals of different colors, depending on nature of the metal ion. Some physical and analytical data are given in Table 1.

\section{Mass spectra}

The mass spectra of synthesized azo Schiff thiazol ligand $\left(\mathrm{HL}_{1}\right)$ were recorded at room temperature. The obtained molecular ion peaks confirmed the propsed formulae for the synthesized compounds. The mass spectrum of the ligand showed the molecular ion

Table 2 IR frequencies in $\mathrm{cm}^{-1}$ of azo-Oxime ligands and their complexes

\begin{tabular}{|c|c|c|c|c|c|c|c|c|c|c|c|}
\hline No. & Compound & $\begin{array}{c}v(\mathrm{O}-\mathrm{H}) \\
\text { water }\end{array}$ & $\begin{array}{l}v(\mathrm{O}-\mathrm{H}) \\
\text { phenol }\end{array}$ & $\begin{array}{c}(\mathrm{C}-\mathrm{H}) \\
\text { ar }\end{array}$ & $\begin{array}{c}(\mathrm{C}-\mathrm{H}) \\
\text { alf }\end{array}$ & $\begin{array}{c}v(\mathrm{C}=\mathrm{N}) \\
\text { schiff }\end{array}$ & $\begin{array}{l}v(\mathrm{C}=\mathrm{N}) \\
\text { thiazol }\end{array}$ & $v(\mathrm{~N}=\mathrm{N})$ & $v(\mathrm{C}-\mathrm{Br})$ & $v(\mathrm{M}-\mathrm{O})$ & $v(\mathrm{M}-\mathrm{N})$ \\
\hline 1 & $\mathrm{HL}_{1}$ & -- & 3423 & 3059 & 2831 & 1666 & 1591 & 1469 & 677 & -- & -- \\
\hline 2 & {$\left[\mathrm{Co}\left(\mathrm{HL}_{1}\right)_{2}\right]\left(\mathrm{H}_{2} \mathrm{O}\right)_{2}$} & 3415 & -- & 3063 & 2927 & 1627 & 1585 & 1462 & 678 & 524 & 449 \\
\hline 3 & {$\left[\mathrm{Ni}\left(\mathrm{HL}_{1}\right)_{2}\right]\left(\mathrm{H}_{2} \mathrm{O}\right)_{2}$} & 3387 & -- & 3062 & 2927 & 1622 & 1583 & 1465 & 677 & 516 & 445 \\
\hline 4 & {$\left[\mathrm{Cu}\left(\mathrm{HL}_{1}\right)_{2}\right]\left(\mathrm{H}_{2} \mathrm{O}\right)_{2}$} & 3414 & -- & 3061 & 2931 & 1651 & 1589 & 1465 & 678 & 520 & 451 \\
\hline 5 & {$\left[\mathrm{Zn}\left(\mathrm{HL}_{1}\right)_{2}\right] \mathrm{H}_{2} \mathrm{O}$} & 3439 & -- & 3061 & 2937 & 1651 & 1583 & 1463 & 677 & 514 & 447 \\
\hline 6 & {$\left[\mathrm{Cd}\left(\mathrm{HL}_{1}\right)_{2}\right] \mathrm{H}_{2} \mathrm{O}$} & 3437 & -- & 3061 & 2931 & 1654 & 1581 & 1465 & 678 & 513 & 428 \\
\hline 7 & {$\left[\mathrm{Hg}\left(\mathrm{HL}_{1}\right)_{2}\right] \mathrm{H}_{2} \mathrm{O}$} & 3437 & -- & 3062 & 2934 & 1662 & 1585 & 1465 & 675 & 514 & 443 \\
\hline
\end{tabular}

Table 3 Spectral data, magnetic moment, conductivities and proposed structure of prepared complexes

\begin{tabular}{|c|c|c|c|c|c|c|c|}
\hline No. & Complex & Assignment & $\begin{array}{l}\text { Absorpiton } \\
\text { band }\left(\mathrm{cm}^{-1}\right)\end{array}$ & $\lambda_{\max }(\mathrm{nm})$ & $\mu_{\text {eff }}($ B.M) & $\begin{array}{c}\mathrm{L}_{\mathrm{M}}\left(\mathrm{S} \mathrm{m}^{2} \mathrm{~mol}^{-1}\right) \\
\text { in DMSO }\end{array}$ & Proposed structure \\
\hline 1 & {$\left[\mathrm{Co}\left(\mathrm{HL}_{1}\right)_{2}\right]\left(\mathrm{H}_{2} \mathrm{O}\right)_{2}$} & $\begin{array}{c}\text { C. } \mathrm{T} \\
{ }^{4} \mathrm{~T}_{1} \mathrm{~g}{ }^{\circledR}{ }^{4} \mathrm{~A}_{2} \mathrm{~g}\end{array}$ & $\begin{array}{l}26385 \\
25510 \\
15384\end{array}$ & $\begin{array}{l}379 \\
392 \\
650\end{array}$ & 2.92 & 13.64 & $\mathrm{Oh}$ \\
\hline 2 & {$\left[\mathrm{Ni}\left(\mathrm{HL}_{1}\right)_{2}\right]\left(\mathrm{H}_{2} \mathrm{O}\right)_{2}$} & $\begin{array}{c}\text { C. } \mathrm{T} \\
{ }^{3} \mathrm{~A}_{2} \mathrm{~g} \rightarrow{ }^{3} \mathrm{~T}_{1} \mathrm{~g} \\
{ }^{3} \mathrm{~A}_{2} \mathrm{~g} \rightarrow{ }^{3} \mathrm{~T}_{1} \mathrm{~g}\end{array}$ & $\begin{array}{l}26954 \\
13003 \\
23148\end{array}$ & $\begin{array}{l}371 \\
769 \\
432\end{array}$ & 4.81 & 12.11 & $\mathrm{Oh}$ \\
\hline 3 & {$\left[\mathrm{Cu}\left(\mathrm{HL}_{1}\right)_{2}\right]\left(\mathrm{H}_{2} \mathrm{O}\right)_{2}$} & $\begin{array}{c}\text { C.T } \\
{ }^{2} \mathrm{~B}_{1} \mathrm{~g} \rightarrow{ }^{2} \mathrm{~A}_{1} \mathrm{G}\end{array}$ & $\begin{array}{l}25773 \\
22624 \\
23474 \\
11098\end{array}$ & $\begin{array}{l}388 \\
442 \\
426 \\
\\
901\end{array}$ & 1.72 & 11.28 & Oh \\
\hline 4 & {$\left[\mathrm{Zn}\left(\mathrm{HL}_{1}\right)\right]_{2} \mathrm{H}_{2} \mathrm{O}$} & C. T. & 26385 & 379 & Dia & 12.91 & Th \\
\hline 5 & {$\left[\mathrm{Cd}\left(\mathrm{HL}_{1}\right)_{2}\right] \mathrm{H}_{2} \mathrm{O}$} & C. T. & 34482 & 384 & Dia & 11.83 & Th \\
\hline 6 & {$\left[\mathrm{Hg}\left(\mathrm{HL}_{1}\right)_{2}\right] \mathrm{H}_{2} \mathrm{O}$} & C. T. & 25906 & 386 & Dia & 14.18 & Th \\
\hline
\end{tabular}


peak at mass-to-charge ratio (m/z) $387+4 \mathrm{H}(7 \%)$ for compound $\mathrm{C}_{16} \mathrm{H}_{11} \mathrm{~N}_{4} \mathrm{OSBr}$ confirmed the proposed formula for the synthesized product. Also, the spectrum exhibited the strongest base peak $\mathrm{m} / \mathrm{z}$ 157(37\%), representing the stable species $\mathrm{C}_{6} \mathrm{H}_{5} \mathrm{Br}$. Moreover, the spectrum exhibited the fragments at $\mathrm{m} / \mathrm{z}: 170+\mathrm{H}, 85$ $-2 \mathrm{H}, 188-\mathrm{H}, 68,161+4 \mathrm{H}$, and $217-2 \mathrm{H}$, corresponding to the molecular formula of $\left(\mathrm{C}_{6} \mathrm{H}_{4} \mathrm{NBr}\right)^{+},\left(\mathrm{C}_{3} \mathrm{H}_{3} \mathrm{NS}\right)$, $\left(\mathrm{C}_{10} \mathrm{H}_{8} \mathrm{~N}_{2} \mathrm{~S}\right),\left(\mathrm{C}_{5} \mathrm{H}_{8}\right),\left(\mathrm{C}_{9} \mathrm{H}_{7} \mathrm{NS}\right)^{+},\left(\mathrm{C}_{10} \mathrm{H}_{7} \mathrm{~N}_{3} \mathrm{OS}\right)$, respectively, as shown in Fig. 1 and 2.

\section{${ }^{1} \mathrm{H}-\mathrm{NMR}$ spectra}

The ${ }^{1} \mathrm{H}-\mathrm{NMR}$ spectrum of the azo Schiff thiazol ligand $\mathrm{HL}_{1}$ is shown in Fig. 3. The multiple peaks observed in the range of 7.19-8.80 ppm in ${ }^{1} \mathrm{HNMR}$ spectrum of $\mathrm{HL}_{1}$ were attributed to the aromatic protons, while the proton of the azo-methine group produced a signal that interleaved the range; it appeared as a single signal at the value of $9.1 \mathrm{ppm}$ [9]. Proton of the phenolic hydroxyl group of the salicialdehyde ring

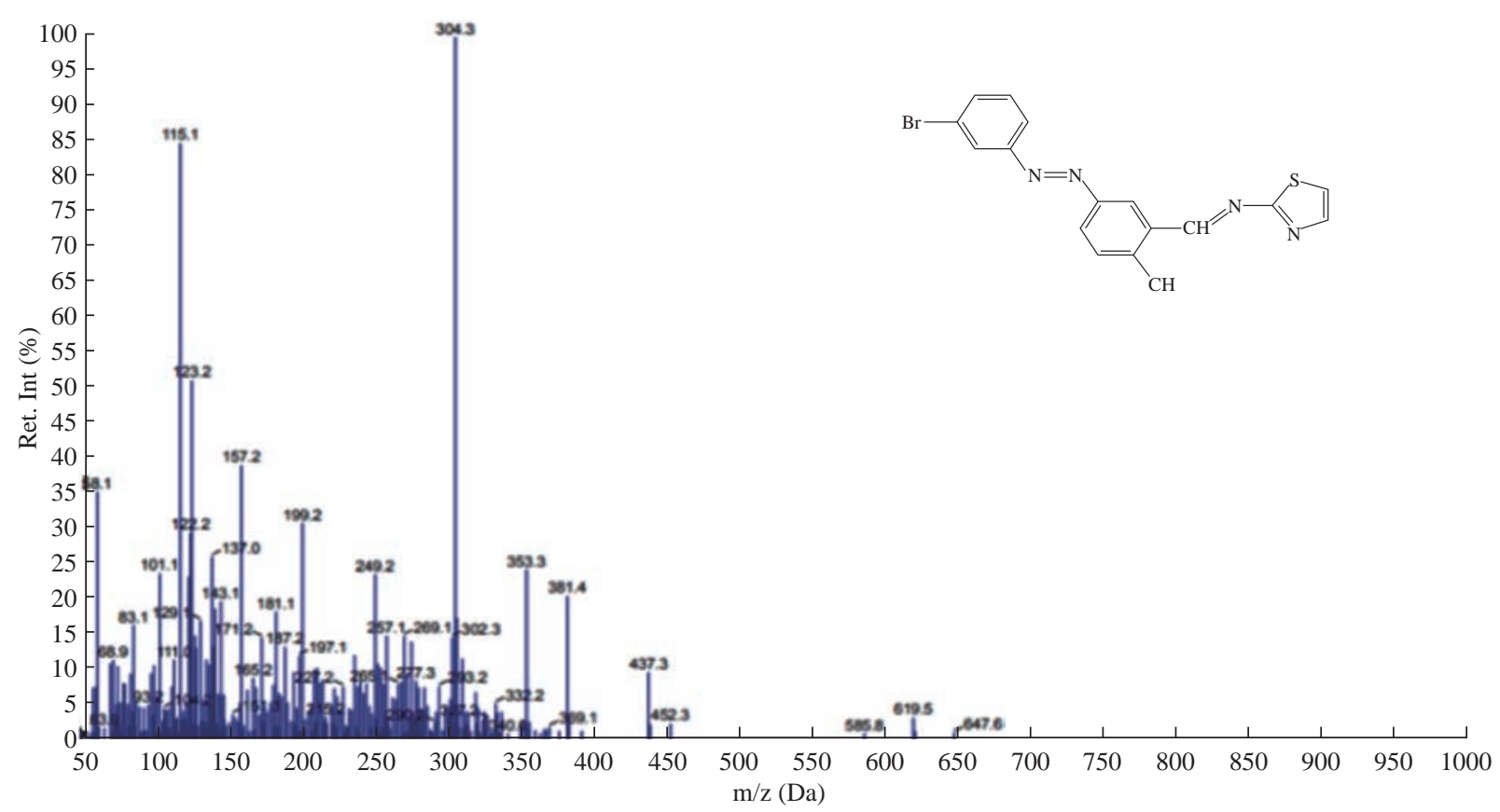

Fig. 1 The mass spectrum of ligand $\mathrm{HL}_{1}$.

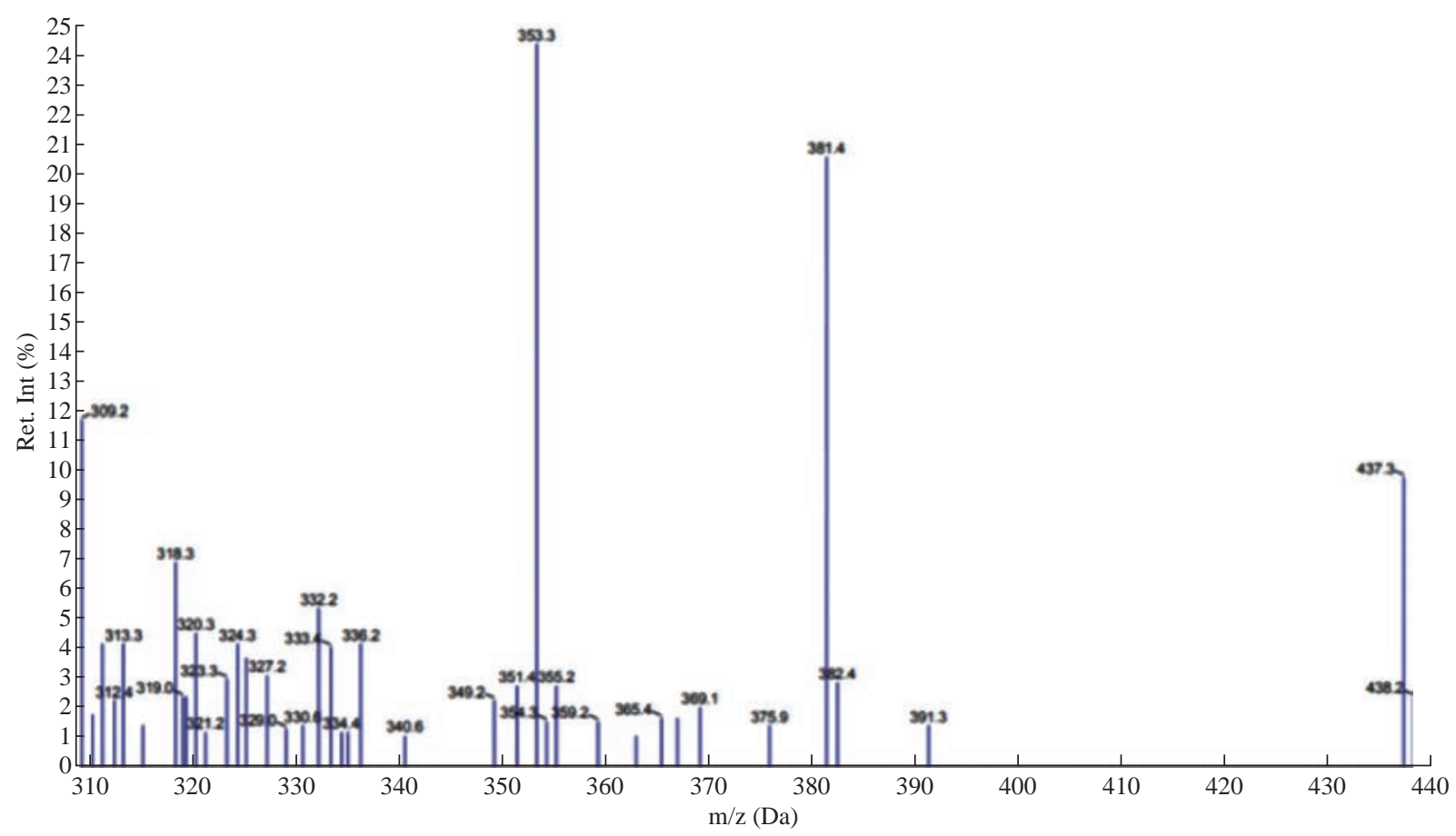

Fig. 2 Mass spectrum of ligand $\mathrm{HL}_{1}$. 
appeared as a single signal at 10.3 [10]. The absence of this peak, noted in the complexes, indicated the loss of the $-\mathrm{OH}$ proton due to the complex ion. There was no appreciable change in all other signals in this complexes as shown in Fig. 4.

\section{Infrared (IR) spectroscopy}

The IR spectra of azo Schiff thiazol ligand $\left(\mathrm{HL}_{1}\right)$ and its metal complexes were studied by using potassium bromide (KBr) disc in the range of $4000-400 \mathrm{~cm}^{-1}$. The shifts in positions or changes in the shape of metal complex bands compared with those absorption bands due to azo Schiff thiazol ligand suggested the probable modes of bonding in the metal complexes.

The IR spectra of the free azo Schiff thiazol ligand $\left(\mathrm{HL}_{1}\right)$ and its metal complexes with $\mathrm{Co}(\mathrm{III}), \mathrm{Ni}(\mathrm{II})$, $\mathrm{Cu}(\mathrm{II}), \mathrm{Zn}((\mathrm{II}), \mathrm{Cd}(\mathrm{II})$ and $\mathrm{Hg}(\mathrm{II})$ are given in Table 2. The IR spectrum of the ligand and copper(II) complex is given in Fig. 5 and 6, respectively. The observed band at $1666 \mathrm{~cm}^{-1}$ was due to $v(\mathrm{C}=\mathrm{N})$ group of the ligand [11]. These bands shifted to lower region during the complex formation, indicating its participation in coordination with the metal ions. The spectra of the metal complexes showed the hydroxyl group with a location, shape and intensity different from the free ligand spectrum, which was due to the association of $v(\mathrm{O}-\mathrm{H})$ with the metal ions after the loss of proton at the formation of the complex. The sharp band at 678 $\mathrm{cm}^{-1}$ was due to $v(\mathrm{C}-\mathrm{Br})$ [12]. In the metal complexes, the aromatic $\mathrm{C}-\mathrm{H}$ stretching bands were observed between 3063 and $3061 \mathrm{~cm}^{-1}$ [13]. The IR spectra of the complex showed a weak beam to medium intensity and at frequencies of $3600-3200 \mathrm{~cm}^{-1}$, due to the asymmetric and asymmetric vibrations of the $\mathrm{H}-\mathrm{O}-\mathrm{H}$ which indicated the presence of water molecules [14].

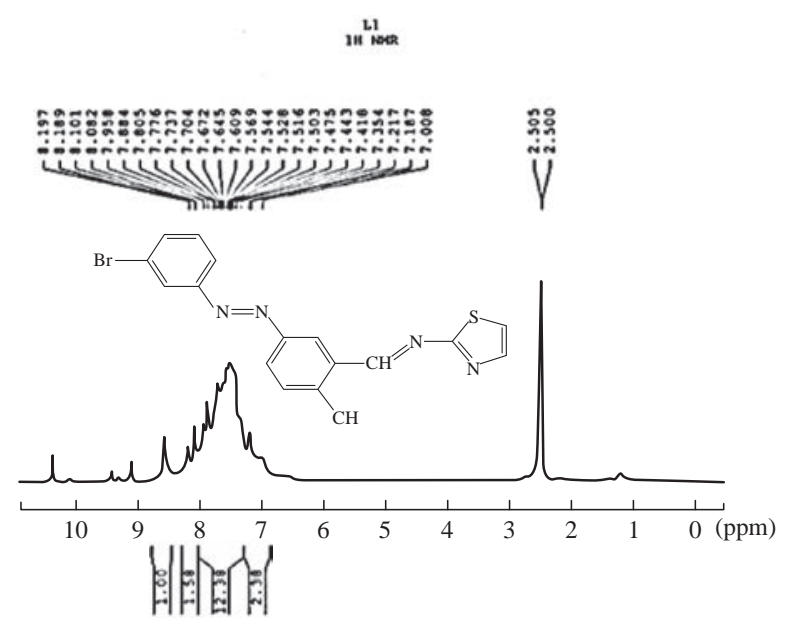

Fig. $3{ }^{1} \mathrm{H}-\mathrm{NMR}$ spectrum of ligand $\mathrm{HL}_{1}$.

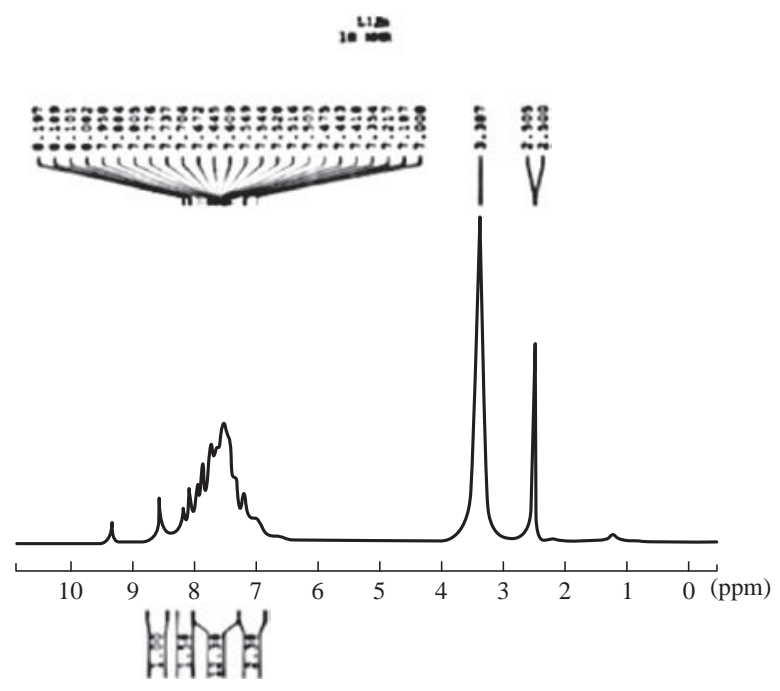

Fig. $4{ }^{1} \mathrm{H}$-NMR spectrum of complex $\left[\mathrm{Zn}\left(\mathrm{HL}_{1}\right)_{2}\right]\left(\mathrm{H}_{2} \mathrm{O}\right)$.

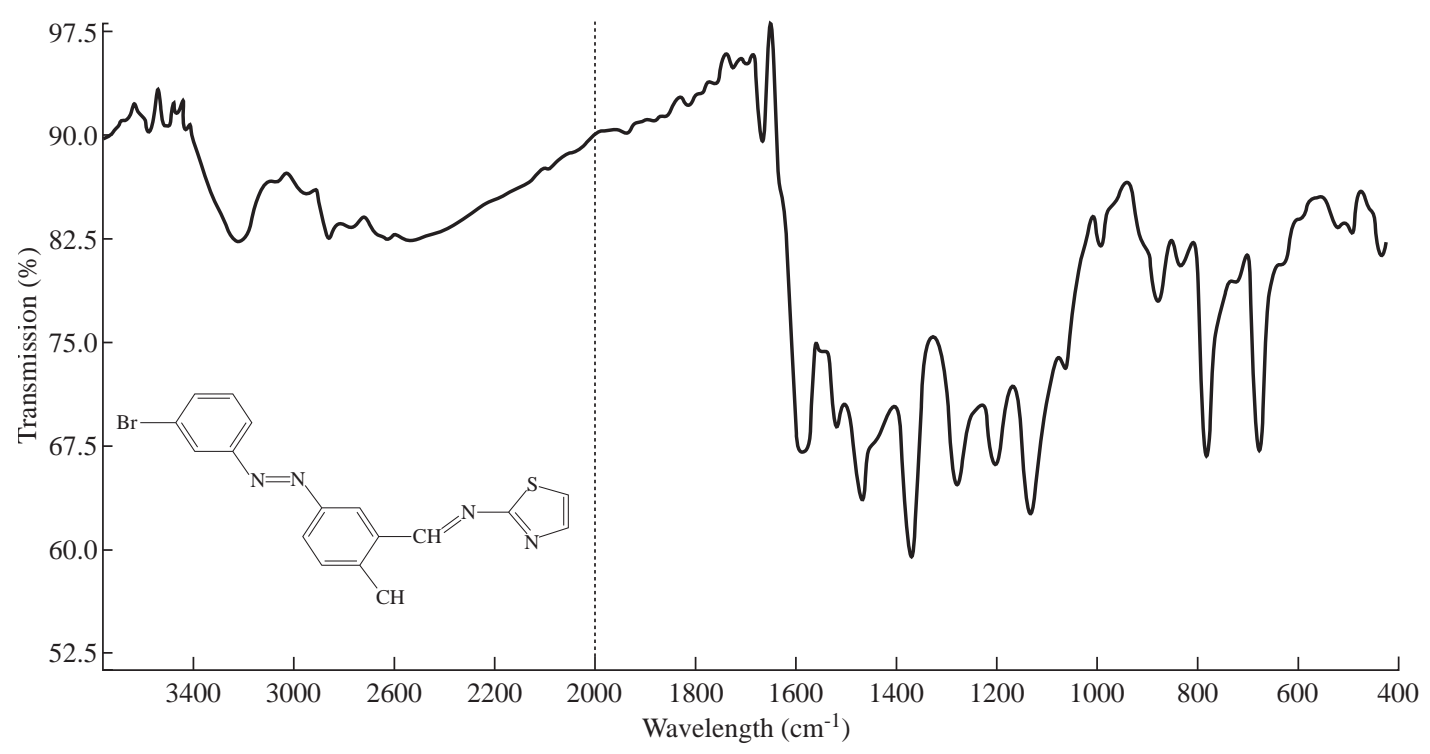

Fig. 5 IR spectroum of ligand $\mathrm{HL}_{1}$. 


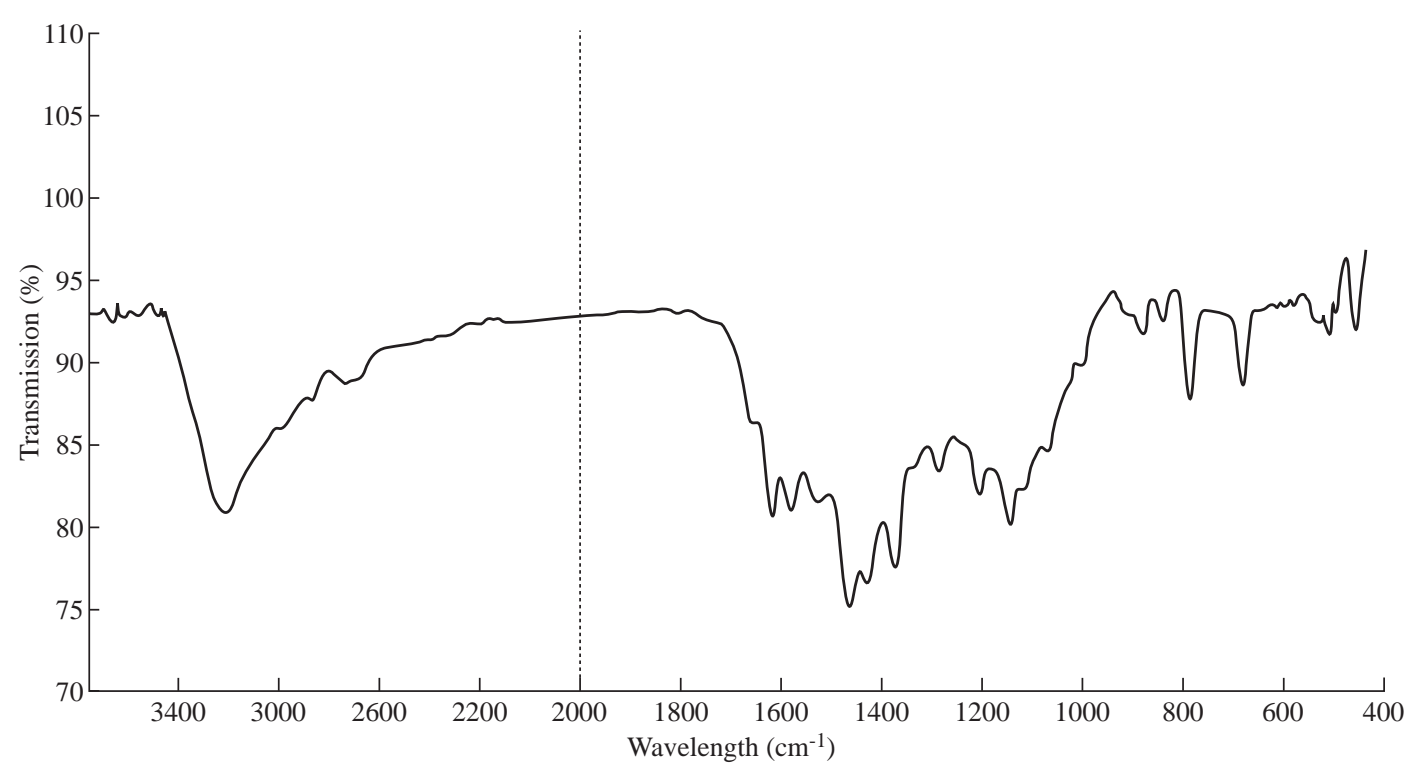

Fig. 6 IR spectroum of $\left[\mathrm{Cu}\left(\mathrm{HL}_{1}\right)_{2}\right]\left(\mathrm{H}_{2} \mathrm{O}\right)_{2}$.

The vibration band of the azo group both in the ligand and in the complexes was seen in the range of 1469$1463 \mathrm{~cm}^{-1}$ [15]. The constant value of its vibration both in the ligand and in the complexes indicated that there was no coordination between the azo group and the metal ions. However, there were two new bands which were not seen in the spectrum of the ligand, appearing also in the spectra of the complexes. The first one was the M-O stretching bands ranging in 513-524 $\mathrm{cm}^{-1}$, which indicated that the ligand was coordinated with the metals through the phenolic hydroxyls. And the second weak band was M-N vibrations seen in 428-44 $\mathrm{cm}^{-1}[16]$.

\section{Magnetic measurements and electronic spectra}

The spectral data and the magnetic moments of each complexes are listed in Table 3.

\section{$\mathrm{HL}_{1}$ ligand}

The UV-Vis spectra of azo Schiff thiazol ligand $\left(\mathrm{HL}_{1}\right)$ and its metal complexes were measured in ethanol at room temperature, and the absorbance maxima are presented in Table 3 . The $\mathrm{HL}_{1}$ ligand was characterized mainly by two absorption bands. The bands at $28.248 \mathrm{~cm}^{-1}$ (354 nm) and $37.174 \mathrm{~cm}^{-1}$ (269 $\mathrm{nm})$ were assigned to $\mathrm{n} \rightarrow \pi^{*}$ and $\pi \rightarrow \pi^{*}$ transitions, respectively in the azo and hydroxyimine groups in the phenyl azo-linked hydroxyimino ligand $\mathrm{HL}_{1}$. The UVvisible spectrum of the $\mathrm{HL}_{1}$ azo Schiff thiazol ligand in ethanol solution is shown in Fig. 7.

\section{Co(II) complex}

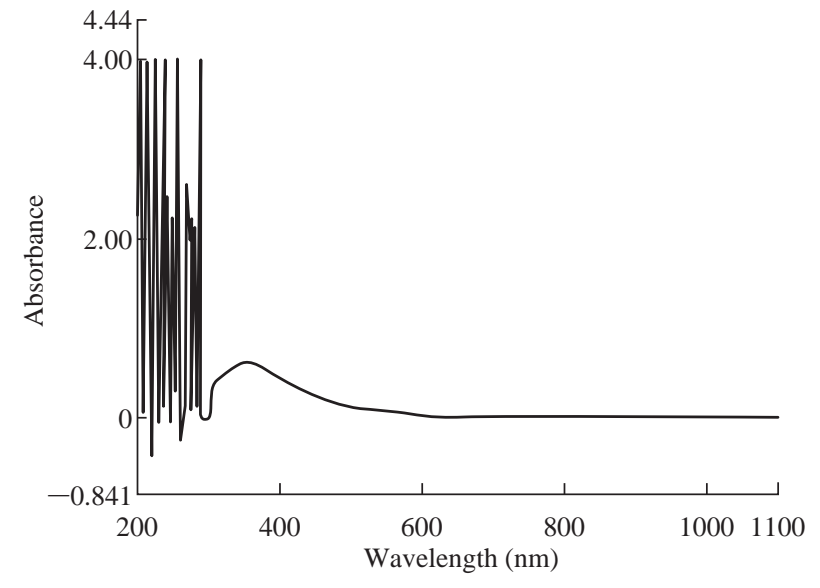

Fig. 7 Ultraviolet-visible spectrum of $\mathrm{HL}_{1}$.

The magnetic measurement showed that Co(II) complexes exhibited magnetic moment of 4.81 B.M laying within the range of octaheadral high spin cobalt(II) complex [17]. The electronic spectrum of this complex showed an absorption band at $15384 \mathrm{~cm}^{-1}$ (650 nm); the ${ }^{4} \mathrm{~T}_{1 \mathrm{~g}} \rightarrow{ }^{4} \mathrm{~A}_{2 \mathrm{~g}}$ transition is characteristic of octahedral stereo chemistry [18].

\section{$\mathrm{Ni}(\mathrm{II})$ complex}

The magnetic measurement showed that $\mathrm{Ni}(\mathrm{II})$ complex exhibited magnetic moment of 2.92 B.M laying within the range of octahedral high spin nickel(II) complex [17]. The electronic spectra of this complex showed two spin-allowed transitions at 23148 $\mathrm{cm}^{-1}$ (432 nm) and $13003 \mathrm{~cm}^{-1}$ (769 nm) corresponding to ${ }^{3} \mathrm{~A}_{2 \mathrm{~g}} \rightarrow{ }^{3} \mathrm{~T}_{2 \mathrm{~g}}$ and ${ }^{3} \mathrm{~A}_{2 \mathrm{~g}} \rightarrow{ }^{3} \mathrm{~T}_{1 \mathrm{~g}}$, respectively [19], as shown in Fig. 8.

Cu(II) complex 


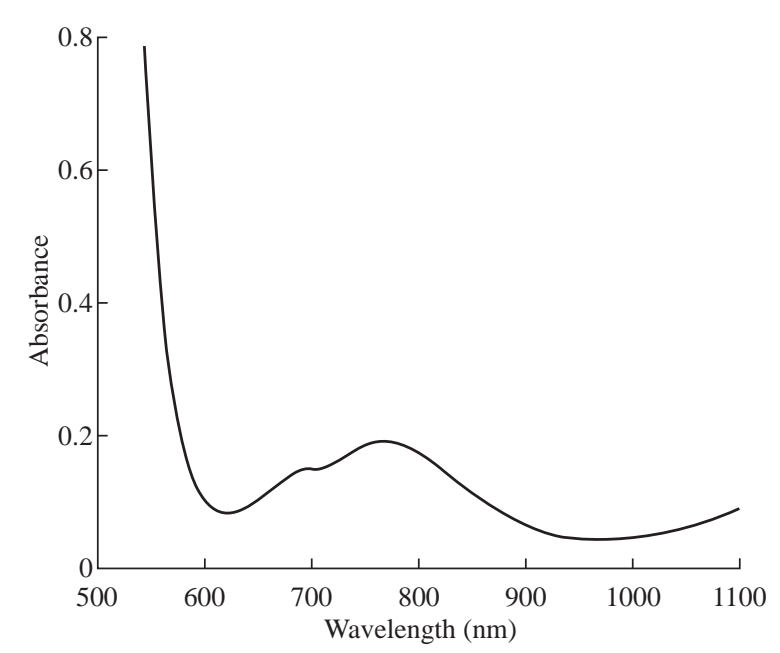

Fig. 8 Ultraviolet-visible spectrum $\left[\mathrm{Ni}\left(\mathrm{HL}_{1}\right)_{2}\right]\left(\mathrm{H}_{2} \mathrm{O}\right)_{2}$.

The value of magnetic moment for this complex was found to be 1.72 B.M due to the presence of one unpaired electron in the compound [20]. The electronic spectra showed a broad absorption band around 11098 $\mathrm{cm}^{-1}$ (901 nm) which was assigned to the transition

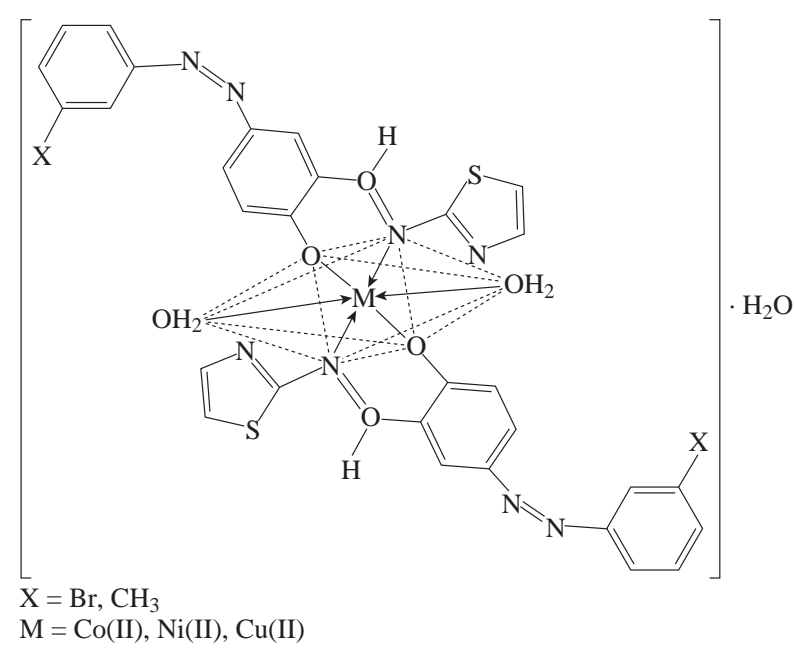

Fig. 9 Suggested geometry of $\mathrm{Co}(\mathrm{II}), \mathrm{Ni}(\mathrm{II})$ and $\mathrm{Cu}(\mathrm{II})$ chelate complexes.
${ }^{2} \mathrm{~B}_{1 \mathrm{~g}} \rightarrow{ }^{2} \mathrm{~B}_{2 \mathrm{~g}}$. It's reasonable to assign distorted octahedral structure [21].

$$
\text { Zn(II), Cd(II) and Hg(II) complexes }
$$

The magnetic susceptibility showed that all these complexes had diamagnetic moments, and the electronic spectra of these complexes did not show any d-d transition band. It's reasonable to assign tetrahedral structure.

\section{Antibacterial activity}

The effect of the ligand $\mathrm{HL}_{1}$ and its complexes were tested for invertor growth inhibitory activity against the gram-positive bacterium Staphylococcus aureus and gram-negative Pseudomonas aeruginosa by using the well-diffusion method, all the tested compounds showed a remarkable anti-bacterial activity against the tested bacteria. The result are listed in Table 4 and its statistical presentation is shown in Fig. 11. It was revealed that the metal complexes were more active than the free ligand, and such enhanced activity of

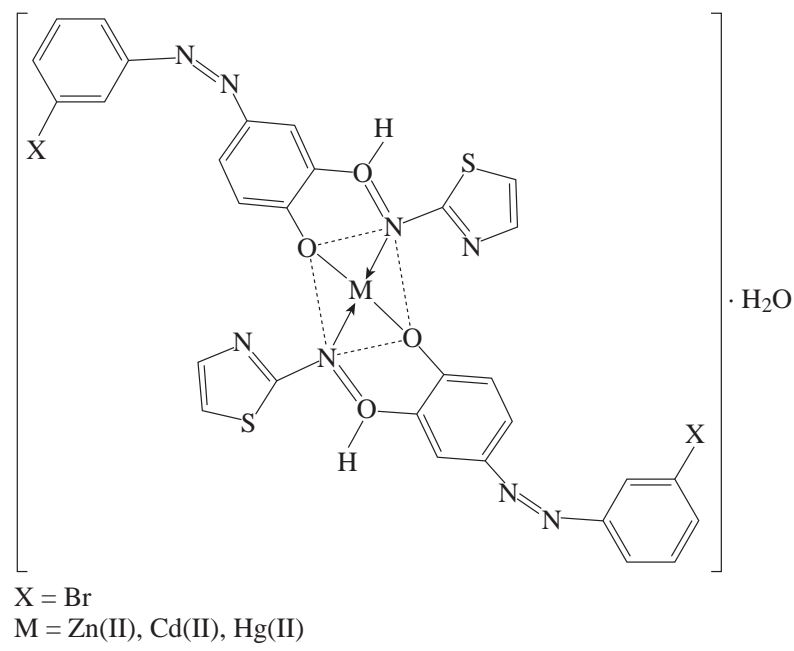

Fig. 10 Suggested geometry of $\mathrm{Co}(\mathrm{II}), \mathrm{Ni}(\mathrm{II})$ and $\mathrm{Cu}(\mathrm{II})$ chelate complexes.

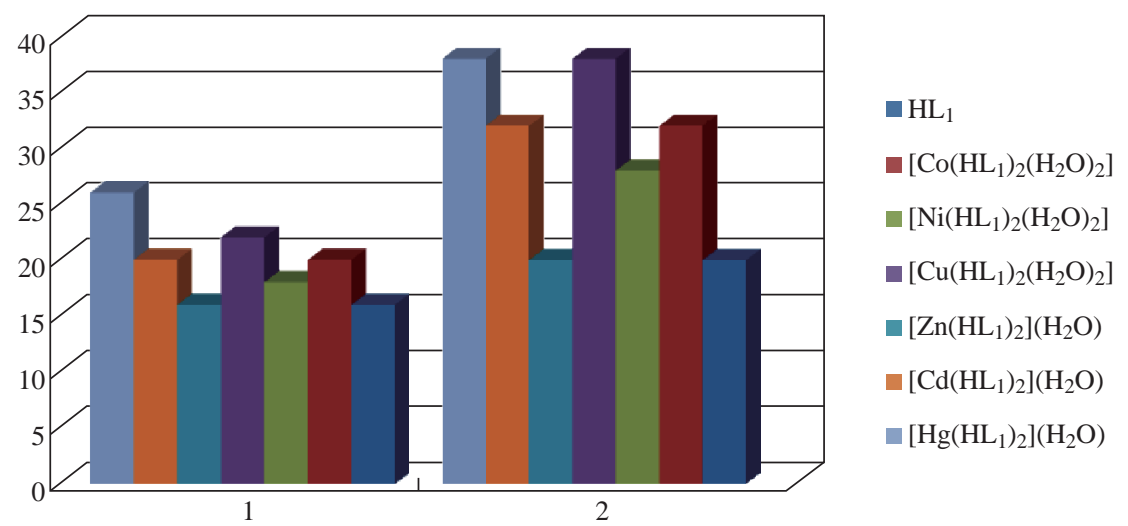

Fig. 11 Statistical representation for anti-bacterial activity of ligand $\left(\mathrm{HL}_{1}\right)$ and its metal complexes at (100 ppm) conc. Inhibition zone of (a) Staphylococcus aureus and (b) Pseudomonas aeruginosa. 
Table 4 Antibacterial activity data (zone of inhibition in millimetre) of the ligand and its metal complexes at the concentration of 100 ppm

\begin{tabular}{ccc}
\hline & \multicolumn{2}{c}{ Bacteria } \\
\cline { 2 - 3 } Compound & Gram-positive: Staphylococcus aureus & Gram-negative: Pseudomonas aeruginosa \\
\hline $\mathrm{HL}_{1}$ & 18 & 20 \\
{$\left[\mathrm{Co}\left(\mathrm{HL}_{1}\right)_{2}\right]\left(\mathrm{H}_{2} \mathrm{O}\right)_{2}$} & 20 & 32 \\
{$\left[\mathrm{Ni}\left(\mathrm{HL}_{1}\right)_{2}\right]\left(\mathrm{H}_{2} \mathrm{O}\right)_{2}$} & 18 & 38 \\
{$\left[\mathrm{Cu}\left(\mathrm{HL}_{1}\right)_{2}\right]\left(\mathrm{H}_{2} \mathrm{O}\right)_{2}$} & 22 & 20 \\
{$\left[\mathrm{Zn}\left(\mathrm{HL}_{1}\right)_{2}\right]\left(\mathrm{H}_{2} \mathrm{O}\right)$} & 16 & 32 \\
{$\left[\mathrm{Cd}\left(\mathrm{HL}_{1}\right)_{2}\right]\left(\mathrm{H}_{2} \mathrm{O}\right)$} & 20 & 38 \\
{$\left[\mathrm{Hg}\left(\mathrm{HL}_{1}\right)_{2}\right]\left(\mathrm{H}_{2} \mathrm{O}\right)$} & 26 & 38 \\
\hline
\end{tabular}

Note: Highlyactive, Inhibition zone > $12 \mathrm{~mm}$; Moderate, Inhibition zone = 9-12 mm; Silight, Inhibition zone = 7-8 mm; Inactive, Inhibition zone = 6 .
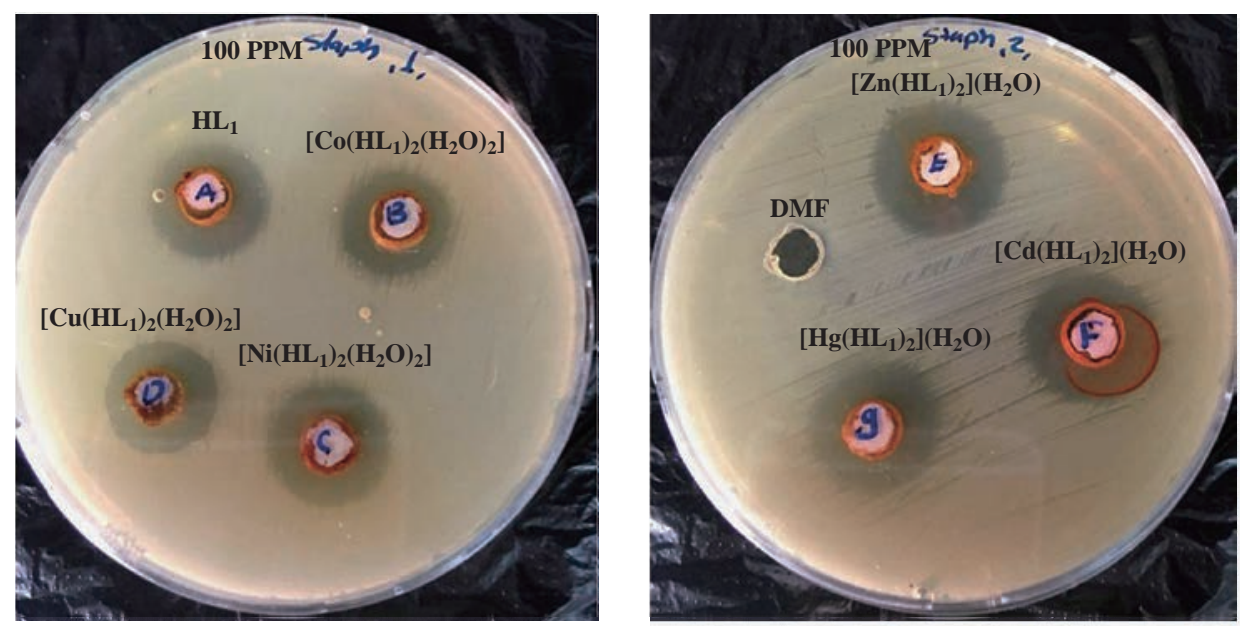

Fig. 12 Effect of ligand $\mathrm{HL}_{1}$ and its metallic complexes on the growth of bacterium Staphylococcus aureus.

metal chelates was due to the lipophilic nature of metal ions in complexes [22]. It was also suggested that the complexes possessed antibacterial activity inhibiting multiplication process of microbes by blocking their active sites [23]. The ligand showed higher effect against all the tested bacteria strains except Pseudomonas aeruginosa, Staphylococcus aureus both of the complexes were shown $\mathrm{Co}(\mathrm{II}), \mathrm{Ni}(\mathrm{II}), \mathrm{Cu}(\mathrm{II})$, Zn(II), Cd(II), Hg(II).

The higher biological activity of metal complexes than the free ligand can be explained on the basis of Overtone's concept and Tweedy's chelation theory [24]. The mechanism of antibacterial drugs can be discussed under four headings: (1) inhibition of cell wall, (2) inhibition of cell membrane function, (3) inhibition of protein synthesis, and (4) inhibition of nucleic acid [25]. Finally, the toxicity of $\mathrm{Ni}(\mathrm{II}), \mathrm{Cu}(\mathrm{II}), \mathrm{Zn}(\mathrm{II}), \mathrm{Cd}(\mathrm{II})$ and $\mathrm{Hg}(\mathrm{II})$ complexes was found to be better than the ligand.

\section{Conclusions}

In the present study, the preparation and characterization of $\mathrm{Co}(\mathrm{II}), \mathrm{Ni}(\mathrm{II}), \mathrm{Cu}(\mathrm{II}), \mathrm{Zn}(\mathrm{II})$, $\mathrm{Cd}(\mathrm{II})$ and $\mathrm{Hg}(\mathrm{II})$ complexes of 4-((E)-(3-bromo phenyl)diazenyl)-2-((E)-(thiazol-2-ylimino)methyl) phenol $\left(\mathrm{HL}_{1}\right)$ were carried out and charachterized by mass spectrum, ${ }^{1} \mathrm{H}-\mathrm{NMR}$, IR spectroscopy and UVVis studies. Electronic spectral data and magnetic susceptibility measurements supported octahedral geometry of the $\mathrm{Co}(\mathrm{II}), \mathrm{Ni}(\mathrm{II})$ and $\mathrm{Cu}(\mathrm{II})$ complexes, while tetrahedral geometry for Zn(II), Cd(II) and $\mathrm{Hg}$ (II) complexes. The complexes were found to have higher biological activities as compared to the respective ligand.

\section{Conflict of Interests}

The authors declare that no competing interest exists. 


\section{References}

[1] R. Carballo, J.S. Casas, and E.G. Arcia-Martinez, 2,5-Dihydro-3,4-dimethyl-5-oxo-1H-pyrazole-1carbothioamide. Acta Crystallographica Section E: Structure Reports Online, 2002, 58(7): 787-789.

[2] A.A.S. Al-Hamdani, S.A. Shaker, Synthesis, characterization, structural studies and biological activity of a new Schiff base-azo ligand and its complexation with selected metal ions. Oriental Journal of Chemistry, 2011, 27(3): 835-845.

[3] A.N. Alaghaz, Y.A. Ammar, Synthesis, spectral characterization, thermal analysis, molecular modeling and antimicrobial activity of new potentially $\mathrm{N}_{2} \mathrm{O}_{2}$ azo-dye Schiff base complexes. Journal of Molecular Structure, 2014, 1074: 359-375.

[4] H. Naeimi, K. Rabiei, and F. Salimi, Efficient and facile synthesis and characterization of novel Schiff bases and their complexes with transition metal ions. Dyes and Pigments, 2007, 75(2): 294-297.

[5] G.M. Malik, S.K. Zadafiya, Thaizole based disperse dyes and their dyeing application on polyester fiber and their antimicrobial activity. Chem. Sin., 2010, 1: 15-21.

[6] E. Erdem, E.Y. Sari, R. Kilicarslan,et al., Synthesis and characterization of azo-linked Schiff bases and their nickel (II), copper (II), and zinc (II) complexes. Transition Metal Chemistry, 2009, 34(2): 167-174.

[7] B.T. Thaker, J.B. Kanojiya, and R.S. Tandel, Effects of different terminal substituents on the mesomorphic behavior of some azo-Schiff base and azo-ester-based liquid crystals. Molecular Crystals and Liquid Crystals, 2010, 528(1): 120-137.

[8] N. Raman, J.D. Raja, Synthesis, structural characterization and antibacterial studies of some biosensitive mixed ligand copper(II) complexes. Indian Jouranol of Chemistry, 2007, 46A: 1612.

[9] N.G. El-Kholy, Synthesis, Spectroscopic characterization, antimicrobial, antitumor properties of new 4-amino-2, 3 dimethyl-1-phenyl-3-pyrazolone-5-one (antipyrine) Schiff bases and its transition metal complexes. Journal of American Science, 2017, 13(2): 132-145.

[10] I. Karim, A Aoun, and A.H. Khafagy, Preparation, characterization and biological study of new azo-oxime ligand and some of its metal complexes. Kufa Journal for Chemistry, 2018, 2(3).

[11] M.A. Neelakantan, M. Esakkiammai, S.S. Mariappan, et al., Synthesis, characterization and biocidal activities of some schiff base metal complexes. Indian Journal of Pharmaceutical Sciences, 2010, 72(2): 216.

[12] B. Revathi, Potentially useful to NLO materials: 4-chloro3-(trifluoromethyl) aniline, 4-bromo-3-(trifluoromethyl) aniline and 4-fluoro-3-(trifluoromethyl) aniline are combined experimental and theoretical vibrational analysis. Journal of Molecular Structure, 2017, 1141: 8192.

[13] A.S. Shawali, M.A. Abdaliah, Substituent effects on azo coupling of indoles. Canadian Journal of Chemistry,
1993, 71(12): 2144-2149.

[14] S. Sarkar, S. Biswas, et al., An attempt towards coordination supramolecularity from $\mathrm{Mn}(\mathrm{II}), \mathrm{Ni}(\mathrm{II})$ and $\mathrm{Cd}(\mathrm{II})$ with a new hexadentate $\left[\mathrm{N}_{4} \mathrm{O}_{2}\right]$ symmetrical Schiff base ligand: Syntheses, crystal structures, electrical conductivity and optical properties. Polyhedron, 2008, 27(16): 3359-3370.

[15] C. Spinu, A. Kriza, Co(II), Ni(II) and Cu(II) complexes of bidentate Schiff bases. Acta Chimica Slovenica, 2000, 47(2): 179-186.

[16] M .Kurtoğlu, S.A. Baydemır, Studies on mononuclear transition metal chelates derived from a novel (E, E)dioxime: Synthesis, characterization and biological activity. Journal of Coordination Chemistry, 2007, 60(6): 655-665.

[17] M. Bal, G. Ceyhan, Synthesis and X-ray powder diffraction, electrochemical, and genotoxic properties of a new azo-Schiff base and its metal complexes. Turkish Journal of Chemistry, 2014, 38(2): 222-241.

[18] O.A. El-Gammal, M.M. Bekheit, and S.A. El-Brashy, Synthesis, characterization and in vitro antimicrobial studies of $\mathrm{Co}(\mathrm{II}), \mathrm{Ni}(\mathrm{II})$ and $\mathrm{Cu}(\mathrm{II})$ complexes derived from macrocyclic compartmental ligand. Spectrochimica Acta Part A: Molecular and Biomolecular Spectroscopy, 2015, 137: 207-219.

[19] N. Kimura, Observation of reciprocal induced CD between Colloidal gold nanoparticles and chiral Schiff base Zn(II) complexes with parallel dipole moments. Journal of Chemistry and Chemical Engineering, 2013, 7(5): 390 .

[20] M.S. Nair, R.S. Joseyphus, Synthesis and characterization of $\mathrm{Co}(\mathrm{II}), \mathrm{Ni}(\mathrm{II}), \mathrm{Cu}(\mathrm{II})$ and $\mathrm{Zn}$ (II) complexes of tridentate Schiff base derived from vanillin and DL- $\alpha$-aminobutyric acid. Spectrochimica Acta Part A: Molecular and Biomolecular Spectroscopy, 2008, 70(4): 749-753.

[21] S.E. Al-Mukhtar, I.A. Mustafa, Inorganic and coordination chemistry. Mosul University, Iraq, 1988.

[22] A.H. Al-Khafagy, Synthesis, characterization and biological study of some new metal-azo chelate complexes. J. Chem. Pharm. Res, 2016, 8(8): 296-302.

[23] R.S. Joseyphus, M.S. Nair, Antibacterial and antifungal studies on some schiff base complexes of zinc(II). Mycobiology, 2008, 36(2): 93-98.

[24] T.D. Thangadurai, K. Natarajan, Mixed ligand complexes of ruthenium (II) containing $\alpha, \beta$-unsaturated- $\beta$ ketoaminesand their antibacterial activity. Transition Metal Chemistry, 2001, 26(4-5): 500-504.

[25] Z.J. Mohammed, A.H. AL-Khafagy, and A.M. Ali, Preparation, characterization and biological study of heterocyclic azo-schiff base compound and some of its metal complexes. Int. J. Currant, 2013, 5(12) :3705-3710.

Copyright $($ Eateman Salah Mahdi, Raheem Tahir Mahdi AlSa>edi. This is an open-access article distributed under the terms of the Creative Commons Attribution License, which permits unrestricted use, distribution, and reproduction in any medium, provided the original author and source are credited. 